\title{
IMPLEMENTASI TQM MELALUI PELATIHAN MODEL IN HOUSE TRAINING UNTUK MENINGKATKAN KOMPETENSI PEDAGOGIK GURU SD
}

\author{
Sri Giarti \& Suhandi Astuti \\ sgiarty@gmail.com \& suhandiastuti@gmail.com \\ Magister Manajemen Pendidikan - FKIP - UKSW Salatiga
}

\begin{abstract}
ABSTRAK
Tujuan penelitian ini adalah untuk meningkatkan kompetensi pedagogik guru SD melalui pelatihan in House Training. Jenis penelitian yang digunakan dalam penelitian ini adalah penelitian tindakan sekolah. Kegiatan dalam penelitian ini terdiri atas diagnosis, action planning, action taking dan action evaluation. Teknik pengumpulan data menggunakan teknik obeservasi kelas. Instrumen observasi yang digunakan adalah alat penilaian kemampuan guru (APKG) berupa: 1) instrument pengembangan media pembelajaran, 2) instrument penilaian kemampuan guru dalam menyusun rencana pembelajaran. Analisis data yang digunakan adalah teknik analisis deskriptif komparatif. Data kuantitatif yang diperoleh di deskripsikan dalam bentuk kata-kata atau penjelasan. Selanjutkan dilakukan komparasi data untuk memastikan ada tidaknya peningkatan kemampuan guru dalam peningkatan kemampuan guru dalam mengembangkan media pembelajaran dan menyusun perencanaan pembelajaran,. Hasil penelitian menunjukkan temuan bahwa IHT dapat meningkatkan a) kemampuan guru SD Negeri di Salatiga, Kota Salatiga dalam mengembangkan media pembelajaran sebesar 13,4\%. b) meningkakan kemampuan guru SD Negeri di Salatiga dalam menyusun rencana pembelajaran sebesar $31,7 \%$.
\end{abstract}

Kata kunci: TQM, Pelatihan in House Training, Kompetensi Pedagogik

\section{PENDAHULUAN}

Pendidikan merupakan bagian penting dari upaya meningkatkan harkat dan martabat bangsa secara menyeluruh. Keberhasilan sebuah pendidikan memberikan kontribusi besar dalam pencapaian tujuan pembangunan nasional. Fattah Nanang (2012:43) mengemukakan mengenai pencapaian tujuan pembangunan secara keseluruhan dalam dimensi yang luas yakni dimensi sosial, budaya, ekonomi, dan politik. 1) dalam dimensi sosial, pendidikan akan melahirkan insan-insan yang terpelajar yang berperan penting dalam proses perubahan di masyarakat. 2) dalam dimensi budaya, pendidikan sebagai wahana yang efektif untuk mengajarkan norma, menyosialisasikan nilai, dan menanamkan etos dikalangan masyarakat sehingga mampu mempertahanakan nilai-nilai dan kepribadian bangsa ditengah arus globalisasi yang kuat, 3) dalam dimensi ekonomi, pendidikan akan menghasilkan manusia yang handal sebagai penggerak pembangunan nasional yang 
mampu berdaya saing dalam memasuki persaingan bangsa di era globa, dan 4) dalam dimensi politik, pendidikan mampu mengembangkan kapasitas pribadi menjadi warga negara yang baik dalam upaya membangun masyarakat yang madani dalam perwujudan masyarakat demokrasi.

Dari uraian tentang pencapaian tujuan pembangunan secara keseluruhan nampak jelas bahwa pendidikan diharapkan mampu memberikan perubahan yang lebih baik sesuai dengan perkembangan, tuntutan, dan dinamika dalam menjawab permasalahan-permasalahan yang dihadapai peserta didik. Untuk mewujudkan hal tersebut diperlukan komponen yang saling terkait yakni; mutu sekolah, guru, siswa, kurikulum, dukungan dana, sarana dan prasarana, serta peran serta orang tua.

Dalam rangka peningkatan mutu pendidikan, Departemen Pendidikan Nasional Republik Indonesia menetapkan peraturan Menteri Pendidikan nomor 19 Tahun 2005 tentang Standar Nasional Pendidikan yang mengatakan bahwa Standar Nasional Pendidikan merupakan kriteria minimal sistem pendidikan di Indonesi yang bertujuan untuk menjamin mutu pendidikan nasional dalam rangka mencerdaskan kehidupan bangsa dan membentuk watak serta peradaban bangsa yang bermartabat. SNP berfungsi sebagai dasar dalam perencanaan, pelaksanaan, dan pengawasan pendidikan dalam rangka mewujudkan pendidikan nasional yang bermutu.

Hal ini dimasudkan untuk menjamin mutu pendidikan dalam rangka mencerdaskan kehidupan bangsa dan membentuk watak serta peradaban bangsa yang bermartabat. Namun kenyataannya belum semua satuan pendidikan mampu mencapai mutu pendidikan. Banyak kendala dan penghambat yang dihadapi dalam melakukanmya. Menurut PPMP Badan Pengembangan SDM Pendidikan dan kebudayaan dan Penjaminan Mutu (2012:5) menjelaskan bahwa salah satu kendala dan penghambat satuan pendidikan belum mampu mencapai mutu pendidikan ialah rendahnya budaya penjaminan mutu di satuan pendidikan relatif sangat lemah. Pemjaminan mutu penididkan didasarkan pada pencapaian komponen delapan Standar Nasional Pendidikan (SNP).

Hasil observasi di SD Negeri di Salatiga yang dilakukan oleh penulis mengenai pencapaian komponen SNP menunjukkan bahwa pada komponen standar proses masih rendah yaitu dari 8 guru yang berstatus PNS belum membuat RPP sendiri atau hanya menggunakan RPP cetakan yang sudah jadi. Selanjutnya pada indikator penggunaan IT dalam proses pembelajaran juga masih rendah hal ini ditunjukkan dari 8 guru belum menggunakan media pembelajaran berbasis IT.

Hasil wawancara dengan Kepala Sekolah SD Negeri di Salatiga, rendahnya indikator penyusunan RPP dan penggunaan IT dalam proses pembelajaran. hal ini ditunjukkan oleh: (1) kemampuan guru dalam membuat media pembelajaran berada skor 21,6 atau pada kategori cukup, hal ini diikarenakan sebagian guru memiliki kemampuan dalam mengoperasikan computer namun belum memanfaatkan untuk 
pembelajaran sedangkan sebagian guru memiliki kemampuan yang rendah dalam mengoperasikan computer. (2) kemampuan guru dalam penyusunan rencana pembelajaran berada pada skor 45,1 atau kategori kurang hal ini dikarenakan dari 8 guru belum ada menyusun RPP, hanya menggunakan RPP yang cetak, sehingga rencana pembelajaran belum sesuai dengan karakteristik siswa.

Fenomena rendahnya kompetensi guru dalam menyusun RPP dan pembuatan media berbasis IT perlu diperbaiki. Upaya perbaikan yang dilakukan ialah dengan pelatihan adalah in House Training. Pelatihan in House Training di pilih karena memiliki kelebihan dapat dilakukan dengan peserta minimal 4 orang dan maksimal 15 orang (Danim (2012: 94).

Berdasarkan latar belakang yang telah dipaparkan diatas, permasalahan penelitian yang akan dipecahkan adalah apakah pelatihan in House Training dapat meningkakan kompetensi pedagogik guru dalam menyusun RPP dan pembuatan media pembelajaran, bagaimana pelatihan in House Training dapat meningkatkan kompetensi guru SD dalam menyusun RPP dan pembuatan media pembelajaran. Setelah melakukan pelatihan ini house training ini guru diharapkan mampu menyusun RPP yang sesuai dengan karakteristik siswanya dan guru mampu membuat media pembelajaran.

\section{KAJIAN PUSTAKA}

\section{Total Quality Management (TQM)}

Kehadiran paradigma baru manajemen mutu terpadu yang dikenal dengan Total Quality Management (TQM) menjadi signifikan diterapkan sebagai solusi alternatif bagi peningkatan dan penjaminan mutu lembaga pendidikan (Jasuri, 2014: 14).

Fandy Tjiptono (2003: 4) mengutip pendapat Ishikawa menyatakan bahwa Total Quality Management merupakan perpaduan semua fungsi dari perusahaan ke dalam falsafah holistik yang dibangun berdasarkan konsep kualitas, teamwork, produktivitas, dan pengertian serta kepuasan pelanggan. Soewarso Hardjosoedarmo (2004:1) yang mengatakan bahwa TQM merupakan pelaksanaan perbaikan kualitas secara berkelanjutan yang berfokus pada pelanggan.

Dari berbagai pengertian TQM yang dikemukakan oleh Fandy Tjiptono (2003: 4) dan Soewarso Hardjosoedarmo (2004:1) di atas dapat disimpulkan bahwa hakikat TQM merupakan suatu konsep yang berupaya melaksanakan sistem manajemen bermutu yang berfokus pada pelanggan melalui perbaikan yang terus menerus.

Hakikat TQM yang telah disimpulkan di atas sejalan dengan pandangan Edward Sallis (2011: 59) yang mengatakan bahwa Edward Sallis mengatakan: “...total quality management is a philosophy of continuous improvement, which can 
provide any educational institution with a set of practical tools for meeting and exceeding present and future customers needs, wants, and expectations" (TQM adalah filosofi perbaikan terus-menerus, yang menyediakan seperangkat alat praktis bagi lembaga pendidikan untuk memenuhi kebutuhan pelanggan berupa keinginan dan harapan di waktu sekarang dan masa depan).

Lebih lanjut Fandy Tjiptono (2003: 4) mengutip pendapat Goestsch dan Davis menyebutkan karakteristik TQM berikut: (1) fokus pada pelanggan, baik pelanggan internal maupun eksternal. (2) memiliki obsesi yang tinggi terhadap kualitas. (3) menggunakan pendekatan ilmiah dalam pengambilan keputusan dan pemecahan masalah. (4) memiliki komitmen jangka panjang. (5) membutuhkan kerja sama tim (teamwork). (6) memperbaiki proses secara berkesinambungan. (7) menyelenggarakan pendidikan dan pelatihan. (8) memberikan kebebasan yang terkendali. (9) memiliki kesatuan tujuan. (10) adanya keterlibatan dan pemberdayaan karyawan.

Konsep kunci $T Q M$ adalah berfokus pada pelanggan. Pelanggan ialah sosok yang dilayani, sedangkan perhatian dipusatkan pada kebutuhan dan harapan para pelanggan. Untuk itu dalam melaksanakan TQM harus mengetahui ciri-ciri pelanggannya, dengan mengidentifikasi dan menganalisis kebutuhan dan harapan pelanggan sehingga dapat memuaskan. Perbaikan pada proses secara sistematik, menunjuk pada kondisi dimana setiap kegiatan hendaknya direncanakan dengan baik, dilaksanakan secara cermat, dan hasilnya dievaluasi dibandingkan dengan standar mutu yang ditentukan sebelumnya. Selain itu, bahwa setiap prosedur kerja yang sedang dilaksanakan perlu ditinjau apakah telah mendatangkan hasil yang diharapkan. Bila tidak, maka prosedur itu perlu diubah dan diganti dengan yang lebih baik dan sesuai.

\section{Hakikat Kompetensi Guru}

Guru merupakan tenaga profesional yang bekerja sesuai dengan keahlian yang dimiliki. Rusman (2012:36) menjelaskan bahwa kompetensi guru merupakan kemampuan guru dalam melaksanakan tugasnya dengan tanggung jawab. Senada dengan pendapat Rusman (2012:36), Wina Sanjaya (2013:16) mengartikan kompetensi sebagai unjuk kerja yang dapat dipertanggungjawabkan dalam mencapai tujuan. Berbeda dengan Rusman (2012:36) dan Wina Sanjata (2013:16), Daryanto dan Tasrial (2011:1) menjelaskan bahwa kompetensi merupakan seperangkat pengetahuan, keterampilan, dan perilkau yang harus dimiliki, dihayati, dan dikuasai oleh guru dalam melaksanakan tugas.

Dari definisi kompetensi yang dikemukakan oleh Rusman (2012:36), Wina Sanjata (2013:16), Daryanto dan Tasrial (2011:1) tersebut di atas, ada benang merah tentang hakikat kompetensi, yaitu seperangkat pengetahuan, keterampilan, dan perilaku yang dimiliki dan dikuasai oleh guru dalam melaksanakan tugasnya dengan 
penuh tanggung jawab. Simpulan ini senada dengan ketentuan dalam UndangUndang Nomor 14 Tahun 2005 mengatakan bahwa guru merupakan pendidik profesional dengan tugas utama mendidik, mengajar, membimbing, mengarahkan, melatih, menilai, dan mengevaluasi peserta didik pada satuan pendidikan.

\section{Kompetensi Profesional}

Permen RI No 16 Tahun 2007 menyebutkan bahwa standar kompetensi guru dikembangkan dari keempat kompetensi yang saling berintegrasi. Keempat kompetensi tersebut yaitu; (1) kompetensi pedagogik berarti kemampuan mengelola pembelajaran peserta didik. (2) kompetensi kepribadian yaitu kemampuan kepribadian yang mantap, stabil, dan berwibawa sehingga mampu menjadi teladan bagi peserta didik dan berakhlak mulia. (3) kompetensi sosial ialah kemampuan guru sebagai bagian dari masyarakat untuk berkomunikasi dengan sesame dan lingkungannya. (4) kompetensi profesional yaitu kemampuan penguasaan materi pembela-jaran secara luas dan mendalam yang memungkinkan terintegrasinya pembelajaran dengan penggunaan TIK.

Dari keempat kompetensi guru diatas, dalam penelitian ini yang akan perbaiki ialah kompetensi pedagogik, Secara legal, Standar Kompetensi Pedagogik Guru SD/MI berdasarkan Permen No. 16 Tahun 2007 meliputi : (1) menguasai karakteristik peserta didik dari aspek fisik, moral, sosial, kultural, emosional, dan intelektual, (2) menguasai teori belajar dan prinsip-prinsip pembelajaran yang mendidik, (3) mengembangkan kurikulum yang terkait dengan mata pelajaran/bidang pengembangan yang diampu, (4) menyelenggarakan pembelajaran yang mendidik, (5) memanfaatkan teknologi informasi dan komunikasi untuk kepentingan pembelajaran, (6) memfasilitasi pengembangan potensi peserta didik untuk mengaktualisasikan berbagai potensi yang dimiliki, (7) Berkomunikasi secara efektif, empatik, dan santun dengan peserta didik, (8) menyelenggarakan penilaian dan evaluasi proses dan hasil belajar, (9) memanfaatkan hasil penilaian dan evaluasi untuk kepentingan pembelajaran, dan (10) melakukan tindakan reflektif untuk peningkatan kualitas pembelajaran.

\section{Hakikat In House Training (IHT)}

In House Training (IHT) merupakan program pelatihan yang diselenggarakan di tempat sendiri, sebagai upaya untuk meningkatkan kompetensi guru, dalam menjalankan pekerjaannya dengan mengoptimalkan potensi-potensi yang ada (Sujoko, 2012:40). Danim (2012:94) mendefinisikan In House Training sebagai pelatihan yang dilaksanakan secara internal oleh kelompok kerja guru, sekolah atau tempat lain yang ditetapkan sebagai penyelenggaraan pelatihan yang dilakukan berdasarkan pada pemikiran bahwa sebagian kemampuan dalam meningkatkan kompetensi dan kerier guru tidak harus 
dilakukan secara eksternal, namun dapat dilakukan secara internal oleh guru sebagai trainer yang memiliki kompetensi yang belum dimiliki oleh guru yang lain. Sedangkan peserta IHT minimal 4 orang dan maksimal 15 orang.

Berdasarkan pendapat Sujoko (2012:94) dan Danim (2012:40), nampak bahwa esensi dari $I H T$ merupakan kegiatan interen sekolah untuk meningkatkan kompetensi guru dengan mengoptimalkan potensi dari guru. Lulu Kamaludin (2011:2) dan Meldona (2009:234) menjelaskan bahwa IHT bertujuan untuk: a) meningkatkan kualitas Sumber Daya Manusia (SDM); b) memperbaiki kinerja, c) menciptakan interaksi antara peserta; d) mempererat rasa kekeluargaan dan kebersamaan; serta e) meningkatkan motivasi dan budaya belajar yang berkesinambungan. Selanjutnya Lulu Kamaludin (2011:2) menyebutkan keuntungan dari penggunaan IHT: (1) hasilnya lebih maksimal, (2) materinya lebih spesifik, (3) biaya lebih murah.

Marwansyah (2012:170) menyebutkan bahwa IHT dilakukan melalui tiga fase, yaitu (1) fase perencanaan, berfungsi untuk menentukan tujuan atau kerangka tindakan yang diperlukan untuk mencapai tujuan tertentu. Kegiatan ini meliputi; menentukan tujuan, menentukan materi, menentukan pendekatan dan metodologi pelatihan, menentukan peserta pelatihan dan fasilitator (trainer), menentukan waktu dan tempat, menentukan semua bahan, menentukan model evaluasi pelatihan, menentukan sumber dana dan pembiayaan yang dibutuhkan. (2) fase proses penyelenggaraan meliputi. mempersiapkan kelengkapan bahan pelatihan dan sarana prasarana. (3) Fase evaluasi adalah fase penilaian terhadap kegiatan pelatihan yang telah dilaksanakan.

Berdasarkan uraian tentang hakikat, tujuan, langkah-langkah iHT seperti telah diuraikan di atas, maka IHT adalah pelatihan guru yang dilaksanakan berdasarkan permintaan pihak sekolah, pesertanya berasal dari satu sekolah, dengan materi pelatihan yang disesuaikan oleh pihak sekolah khususnya dalam pengembangan media, dan dilaksanakan di sekolah tempat guru tersebut bekerja dengan tujuan memperoleh perubahan tingkah laku sehingga dapat meningkatkan dan mengembangkan keahlian, pengetahuan dan sikap melalui tiga fase yaitu perencanaan, penyelenggaraan dengan mempersiapkan kelengkapan bahan dan sarana prasarana dan evaluasi untuk menilai kegiatan pelatihan yang telah dilaksanakan.

\section{Implementasi TQM Melalui Pelatihan Model In House Training Untuk Peningkatan Kompetensi Pedagogik Guru SD}

Konsep TQM berfokus pada pelanggan. Untuk itu dalam melaksanakan TQM harus mengetahui ciri-ciri pelanggannya, dengan mengidentifikasi dan menganalisis kebutuhan dan harapan pelanggan sehingga dapat memuaskan. Oleh 
karena itu perlu adanya perbaikan secara sistematik, yaitu setiap kegiatan hendaknya direncanakan dengan baik, dilaksanakan secara cermat, dan hasilnya dievaluasi kemudian dibandingkan dengan standar mutu yang ditentukan sebelumnya. Selain itu, setiap prosedur kerja yang sedang dilaksanakan perlu ditinjau apakah telah mendatangkan hasil yang diharapkan. Bila tidak, maka prosedur itu perlu diubah dan diganti dengan yang lebih baik dan sesuai.

Implementasi $T Q M$ dalam peningkatkan mutu pendidikan dilakukan melalui perbaikan secara terus menerus demi kepuasan pelanggan yaitu siswa. Oleh karena itu proses pembelajaran harus dilakukan dengan baik sehingga dapat meningkatkan mutu pendidikan. Guru merupakan kunci dalam peningkatan mutu pendidikan karena guru secara langsung berinteraksi dengan sisiwa melalui proses pembelajaran. proses pembelajaran yang berlangsung merupakan langkah awal dalam peningkatan mutu pendidikan. hal ini dimaksudkan bahwa mutu pendidikan dimulai dari proses belajar mengajar yang dilakukan guru di dalam kelas. Oleh karena itu guru harusah memiliki kompetensi yang baik dalam melaksanakan tugasnya.

Namun pada kenyataannya, kompetensi guru masih rendah. Hasil Uji Kompetensi Guru (UKG) tahun 2015 menunjukkan bahwa kompetensi guru di Indonesia masih rendah. Data kemendikbud 2016 (www.kemdikbud.go.id) menyebutkan bahwa rata-rata nasional hasil UKG 2015 untuk kompetensi pedagogik dan profesional adalah 53,02. Berdasarkan data tersebut nampak bahwa kompetensi guru masih rendah.

Rendahnya kompetensi guru perlu diperbaiki. Upaya perbaikan yang dilakukan oleh peneti melalui pelatihan in House Training. Pemilihan pelatihan in House Training diasumsikan dapat meningkatkan kompetensi guru dalam hal ini kompetensi pedagogik guru, dapat dilakukan ditempat sendiri dengan jumlah peserta 4-15 orang.

Berdasarkan alasan tesebut, maka penelitian ini sebagai upaya meningkatkan kompetensi pedagogik guru dengan langkah-langkah: (1) menjelaskan hakikat media pembelajaran, (2) memperkenalkan komputer sebagai scaffolding pembelajaran, (3) menjelaskan bagian-bagian komputer dan fungsinya, (4) menjelaskan langkah-langkah membuat media pembelajaran menggunakan komputer, (5) melatih guru mencari video pembelajaran di youtube, (6) melatih guru mendownload video pembelajaran, (7) mempresentasikan video pembelajaran yang telah didonwoad, (8) menjelaskan langkah-langkah penyusunan RPP, (9) membuat RPP dengan media video pembelajaran, (10) mendiskusikan permasalahan yang dihadapi berkaitan dengan pengaplikasian video pembelajaran dan penyusunan RPP, (11) mengevaluasi untuk mengetahui seberapa pencapaian kemampuan peserta pelatihan dalam menyerap materi yang telah disampaikan selama pelaksanaan iHT. 


\section{METODE PENELITIAN}

Penelitian ini merupakan penelitian tindakan sekolah (PTS) yang dilakukan di SD Negeri Salatiga. Subyek yang dilibatkan dalam penelitian tindakan sekolah ini adalah guru tetap (PNS) dengan jumlah 8. Pelaksanaan penelitian tindakan ini menggunakan langkah-langkah yang diadopsi dari empat langkah penelitian tindakan EMAR, Mcpherson and Nunes (2004:28) yaitu (1) diagnosis, Pada tahap diagnosis ini kegiatan yang dilakukan meliputi observasi, wawancara, studi dokumen untuk mengetahui kebutuhan. (2) action planning, pada tahap perencanaan tindakan ini kegiatan yang dilakukan meliputi, merencanakan program pelatihan, menghubungi Kepala Sekolah, merencakan materi pelatihan. (3) action taking, Peneliti dalam tahap pengambilan tindakan ini menyusun langkah-langkah: (a) menjelaskan hakikat media pembelajaran, (b) memperkenalkan komputer sebagai scaffolding pembelajaran, (c) menjelaskan bagian-bagian komputer dan fungsinya, (d) menjelaskan langkah-langkah membuat media pembelajaran menggunakan komputer, (e) melatih guru mencari video pembelajaran di youtube, (f) melatih guru mendownload video pembelajaran, (g) mempresentasikan video pembelajaran yang telah didonwoad, (h) menjelaskan langkah-langkah penyusunan RPP, (i) membuat RPP dengan media video pembelajaran, (j) mendiskusikan permasalahan yang dihadapi berkaitan dengan pengaplikasian video pembelajaran dan penyusunan RPP (4) action evaluation, mengadakan evaluasi dari tahap diagnosis, perencanaan tindakan, pengambilan tindakan, serta indikator pencapaian keberhasilan.

Sumber data primer berasal dari hasil pengukuran variabel penelitian tindakan sekolah berikut: 1) skor kemampuan guru dalam membuat media pembelajaran. 2) skor kemampuan guru penyusunan rencana pembelajaran. Teknik pengumpulan data menggunakan 1) instrumen evaluasi media pembelajaran, 2) instrument penilaian kemampuan guru dalam menyusun rencana pembelajaran.

Kisi-kisi instrumen evaluasi media pembelajaran mencakup 10 item soal. Sedangkan untuk instrumen kemampuan guru dalam menyusun rencana pembelajaran mencakup 7 komponen yaitu: tujuan pembelajaran (no item 1 dan 2) meteri ajar (no item 3, 4, 5 ), metode pembelajaran (no item 6 dan 7), langkahlangkah pembelajaran (no item $8,9,10$ 11, 12, 13, 14, 15, 16, 17) alat/bahan/sumber belajar (no item 18, 19, 20), penilain (no item 21 dan 22), kesan umum rencana pembelajaran (no item 23, 24, 25).

Instrumen evaluasi media pembelajaran terdapat 4 kualifikasi penilaian yaitu sangat setuju, setuju, tidak setuju dan sangat tidak setuju. Setiap skor yang diperoleh kemudian dibagi dengan skor maksimal dan dikalikan dengan 100 atau $\mathrm{N}=\frac{\text { skor yang diperoleh }}{\text { skor maksimal }} \mathrm{X} 100$. Adapun kriteria penilaian yaitu: Baik Sekali berada di 
skor 33 sampai 40, Baik berada pada skor 24 sampai 32, Cukup berada pada skor 15 sampai 23 , sedangkan Kurang berada pada skor kurang dari 15 .

Sedangkan untuk instrumen penilaian terdapat 5 kualifikasi penilaian yaitu 1, 2, 3, 4 dan 5. Setiap skor yang diperoleh kemudian dibagi dengan skor maksimal dan dikalikan dengan 100 atau $\mathrm{N}=\frac{\text { skor yang diperoleh }}{\text { skor maksimal }} \mathrm{X}$ 100. Adapun kriteria penilaian yaitu: Baik Sekali berada di skor 91 sampai 100, Baik berada pada skor 76 sampai 90, Cukup berada pada skor 61 sampai 75, Kurang berada pada skor 51 sampai 60 sedangkan Kurang Sekali berada pada skor kurang dari 50 .

Analisis data yang digunakan adalah teknik analisis deskriptif komparatif. Data kuantitatif yang diperoleh di deskripsikan dalam bentuk kata-kata atau penjelasan. Selanjutkan dilakukan komparasi data untuk memastikan ada tidaknya peningkatan kemampuan guru dalam menyusun perencanaan pembelajaran, peningkatan kemampuan guru dalam pelaksanaan.

Sebagai tolok ukur keberhasilan pelaksanaan penelitian tindakan kelas ini ditetapkan indikator kinerja sebagi berikut: 1) Persentase jumlah evaluasi media pembelajaran sebesar $10 \%$ dan 2) Persentase jumlah jumlah skor perolehan kemampuan menyusun perencanaan pembelajaran sebesar $25 \%$

\section{HASIL DAN PEMBAHASAN}

Dari hasil studi yang dilakukan menunjukkan bahwa: 1) skor rata-rata (mean) kemampuan guru dalam membuat media pembelajaran mencapai 21,6 (dari skor maksimal 40). Sebaran skornya, ada 4 guru memiliki kemampuan dalam mengoperasikan komputer namun belum memanfaatkan untuk pembelajaran sedangkan 4 guru memiliki kemampuan yang rendah dalam mengoperasikan komputer. (2) pada kondisi awal kemampuan guru dalam penyusunan rencana pembelajaran, rata-rata skor mencapai 5,1 (dari skor ideal 100) distribusinya adalah ada 8 guru belum ada menyusun RPP, hanya menggunakan RPP yang cetak.

Setelah melakukan analisa terhadap data yang diperoleh, maka dapat disimpulkan bahwa penggunaan iHT menunjukkan peningkatan kompetensi pedagogik. Secara visual Tabel 1 merangkum komparasi kemampuan merencanakan pembelajaran, dari kondisi awal, dan tindakan.

Tabel 1 Komparasi Kompetensi Guru

\begin{tabular}{|l|c|c|c|}
\hline \multirow{2}{*}{ Kompetensi guru } & \multicolumn{3}{|c|}{ Pelatihan IHT } \\
\cline { 2 - 4 } & $\begin{array}{c}\text { Kondisi } \\
\text { Awal }\end{array}$ & Tindakan & kenaikan \\
\hline $\begin{array}{l}\text { Membuat media } \\
\text { pembelajaran }\end{array}$ & 21,6 & 35 & $13,4 \%$ \\
\hline Menyusun RPP & 45,1 & 76,8 & $31,7 \%$ \\
\hline
\end{tabular}


Dari data dalam Tabel diatas, diperoleh temuan kemampuan guru dalam membuat media pembelajaran: a) pada kondisi awal, baru mencapai skor 21,6 (skor maksimal 40) atau masuk kategori cukup. Hal ini dikarenakan guru dapat mengoperasikan komputer namun belum mampu memanfaatkan untuk pembelajaran sedangkan sebagian guru belum terampil mengoperasikan komputer. b) pada tindakan, skor guru mencapai 35 atau kategori baik capaian ini menunjukkan peningkatan kemampuan guru dalam membuat media pembelajaran.

Temuan kedua, kemampuan guru dalam menyusun rencana pembelajaran. a) kondisi awal, baru mencapai skor 45,1 (skor maksimal 100) atau masuk dalam kategori kurang. Hal ini disebabkan karena guru beum membuat RPP, guru hanya menggunakan RPP yang sudah ada. b) pada tindakan, skor guru mencapai 76,8 atau kategori sangat baik, capaian ini menunjukkan peningkatan kemampuan guru dalam menyusun rencana pembelajaran.

\section{Keberhasilan iHT dalam meningkatkan kemampuan membuat media pebelajaran}

Data pada tabel kompetensi guru kondisi awal dan tindakan menunjukkan temuan skor kemampuan guru membuat media pembelajaraan pada kondisi awal 21,6 pada tinda setelah diberikan tindakan menjadi 35 . Temuan ini mengindikasikan adanya peningkatan tingkat kemampuan guru menyusun rencana pembelajaran. Besaran peningkatan 13,4\%. Jika dibandingkan dengan indikator kinerja $10 \%$ ternyata temuan tersebut telah mencapai keberhasilan. Hasil temuan ini sejalan dengan penelitian: Heldy Eriston (2011), Sumarni (2014).

\section{Keberhasilan iHT dalam meningkatkan kemampuan menyusun rencana pembelajaran}

Data pada tabel kompetensi guru kondisi awal dan tindakan menunjukkan temuan skor kemampuan guru menyusun rencana pembelajaran pada kondisi awal 45,1 stelah diberikan tindakan 76.8. Temuan ini mengindikasikan adanya peningkatan tingkat kemampuan guru menyusun rencana pembelajaran. Besaran peningkatan $31,7 \%$. Jika dibandingkan dengan indikator kinerja $25 \%$ ternyata temuan tersebut telah mencapai keberhasilan. Hasil temuan ini sejalan dengan: Alfaris Sujoko (2012), Noriko Candra Khaerani (2016).

\section{SIMPULAN}

Berdasarkan hasil penelitian dan pembahasan, dapat disimpulkan bahwa iHT dapat:

1. Meningkakan kemampuan guru SD Negeri di Salatiga dalam membuat media 
pembelajaran sebesar $13,4 \%$.

2. Meningkakan kemampuan guru kelas SD Negeri di Salatiga dalam menyusun rencana pembelajaran sebesar $31,7 \%$.

\section{SARAN}

Saran yang diajukan dalam penelitian ini adalah, peran Kepala Sekolah hendaknya a) menggunakan in House Training dalam meningkatkan kompetensi guru, b) melatih guru untuk berinovasi dalam pembelajaran di kelas, c) mengembangkan keterampilan guru dalam proses pembelajaran.

\section{DAFTAR PUSTAKA}

Alfaris, Sujoko. 2012. Peningkatan Kemampuan Guru Mata Pelajaran Melalui In House Training. Jurnal Pendidikan Penabur-No.18 tahun ke-11/Juni. Diakses dari www.bpkpenabur.or.id tanggal 3 Maret 2016

Danim Sudarwan dan Khairil. 2011. Profesi Kependidikan. Bandung: Alfabeta Sujoko.

Daryanto, Tasrial. 2015. Pengembangan Karir Profesi Guru. Malang: Gava Media

Edward Sallis. 2011. Total Quality Management in Education Manajemen Mutu Pendidikan. Yogjakarta: IRCiSoD.

Eriston, Heldy, 2011. Peningkatan Kemampuan Guru Dalam Membuat Power Point Untuk Media Pembelajaran Melalui In House Training Di SMK Teknik Industry Purwakarta, Laporan Penelitian makalah Tindakan Sekolah, di unduh 10 Oktober 2015. http://www.slideshare. net/Eriston/laporan-pts-ptk-total.

Fandy Tjiptono dan Anastasia Diana. 2003. TQM Quality Management. Yogyakarta: Andi

Fattah Nanang. 2012. Analisa Kebijakan Pendidikan. Bandung: PT Remaja Rosdakarya

Fidiawati, 2012. Efektifitas In House Training dalam Meningkatkan Kompetensi Guru Pkn. Skirpsi Universitas Pendidikan Indonesia, di unduh 9 Oktober 2015. http://repository.upi.edu/skripsiview.php? no_skripsi $=13657$.

Jasuri. 2014. Implementasi Total Quality Management Pada Kelas Internasional dan Akselerasi MTS PPMI Assalaam Surakarta. Tadbir: Jurnal Manajemen Pendidikan Islam 2 (1): 14. 
Kementerian Pendidikan dan Kebudayaan. 2016. http://www.kemdikbud.go.id/ main/blog/2016/01/7-provinsi-raih-nilai-terbaik-uji-kompetensi-guru-2015. Diunduh 1 Maret 2016.

Lulu Kemaludin. Pengertian In House Training, tujuan dan Manfaatnya. http://tikettraining.com/pengertian-in-house-training-tujuan-danmanfaatnya. Diunduh tanggal 2 Maret 2016

Mawansyah. 2010. Manajemen Sumber Daya Manusia. Bandung: Alfabeta

Meldona. 2009. Manajemen Sumber Daya Manusia. Malang : UIN Malang Press.

Noriko Candra Khaerani. 2016. Peningkatan Kompetensi Guru Dalam Menyusun Rpp Melalui Kegiatan Iht (In House Training). Didaktikum : Jurnal Penelitian Tindakan Kelas Vol. 17, No. 1, Januari 2016

Nunes Miguel Baptista, Mc Pherson Maggie. 2004. An Action Research Model For The Management Of Change In Continuing Professional Distance Education Department. London: RoutledgeFalmer

Qory Dellasera. 2013. http://www.kompasiana.com/www.savanaofedelweiss.com /kualitas-pendidikan-indonesia-refleksi-2-mei_5529c509f17e610d25d623ba . Diunduh 1 Maret 2016.

Rusman. 2012. Belajar dan Pembelajaran Berbasis Komputer Mengembangkan Profesionalisme Guru Abad 21. Bandung: Alfabeta

Soewarso Hardjosoedarmo. 2004. Total Quality Management. Yogyakarta: Andi Offset

Sumarni. 2014. Meningkatkan Kemampuan Guru Melalui Pengembangan Media Pembelajaran. Jurnal Penelitian Tindakan Sekolah dan Kepengawasan. 1, (1): 1-15. Edisi Khusus.

Tilar, Nugroho Riant. 2008. Kebijakan Pendidikan. Yogyakarta: Pustaka Pelajar

Wina Sanjaya. 2013. Strategi Pembelajaran Berorientasi Standar Proses Pendidikan. Bandung: Kencana Prenadamedia Grup 2005. Undang-Undang RI No. 19 Th. 2005 Tentang Standar Nasional Pendidikan. .Jakarta:Depdiknas.

2007. Peraturan Menteri Pendidikan Nasional No. 16 Tahun 2007 tentang Standar Kompetensi Guru. Jakarta:Depdiknas 